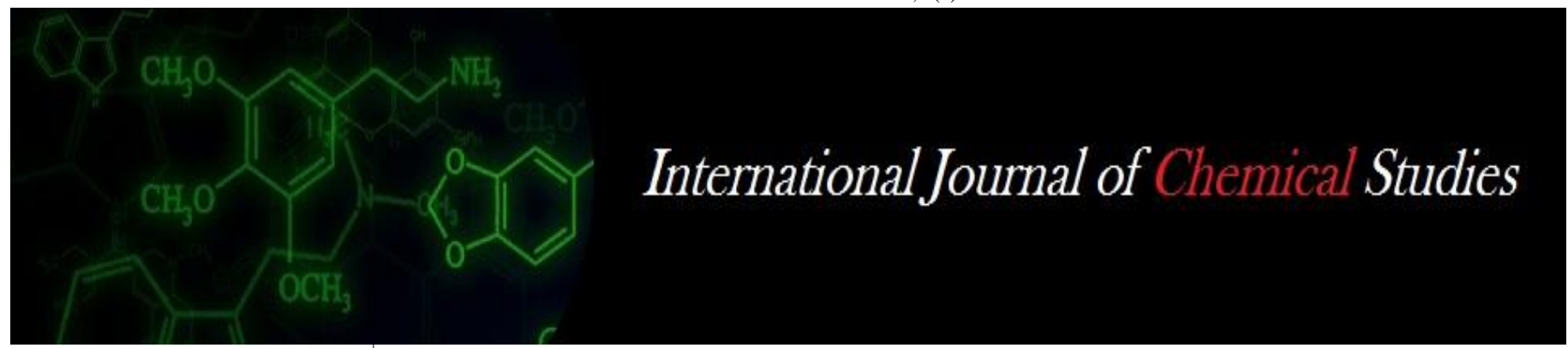

P-ISSN: 2349-8528

E-ISSN: 2321-4902

www.chemijournal.com

IJCS 2020; 8(3): 2979-2983

(C) 2020 IJCS

Received: 26-03-2020

Accepted: 27-04-2020

Nanjundaswamy JC

Department of Plant Pathology

College of Agriculture,

University of Agricultural

Sciences, Dharwad, India.

\section{ST Naik}

Department of Plant Pathology

College of Agriculture,

University of Agricultural

Sciences, Dharwad, India.

\section{Nandan M}

Department of Plant Pathology,

College of Agriculture,

University of Agricultural

Sciences, Bangalore, India
Corresponding Author: Nanjundaswamy JC

Department of Plant Pathology

College of Agriculture,

University of Agricultural

Sciences, Dharwad, India.

\section{Bio efficacy of fungicides, biocontrol agents and botanicals against brown spot (Cercospora longipes Butler) of sugarcane}

\author{
Nanjundaswamy JC, ST Naik and Nandan M
}

DOI: https://doi.org/10.22271/chemi.2020.v8.i3aq.9665

\begin{abstract}
Sugarcane (Saccharum officinarum L.) is an important cash and industrial crop of India. Brown spot of sugarcane is one of miner disease which sporadically has become frequent occurring disease in some parts of northern Karnataka. Pathogenicity of brown spot disease was proved by mycelial bit inoculation method. Further identified the brown spot (Cercospora longipes Butler) pathogen with produced hyaline conidiophore in clusters and conidia were hyaline, two to many celled, needle shaped and produced shy sporulation. In vitro evaluation fungicides, plant extract and bioagents revealed that hexaconazole 5\% $\mathrm{EC}$, propiconazole $25 \mathrm{EC}$ and tebuconazole $250 \mathrm{EC}$ at 0.05 per cent concentration showed cent per cent inhibition of mycelial growth of $C$. longipes in systemic fungicides, mancozeb @ 0.2 and 0.3 per cent concentration showed cent per cent inhibition in non-systemic fungicides, cabendazim $12 \%+$ mancozeb $63 \%$, hexaconazole 18\% + zineb 68\%, captan 70\% + hexaconazole 5\% @ all the concentration and Carboxin 37.55\% + thiram 37.55\% @ 0.1 and 0.2 per cent concentration showed 100 per cent inhibition in combi products, leaf extracts of Azadiracta indica (10\%) and Trichoderma virens were most effective against brown spot.
\end{abstract}

Keywords: Cercospora longipes, Bio Efficacy, fungicides, plant extract and bioagents.

\section{Introduction}

Sugarcane (Saccharum officinarum L) is an important cash and industrial crop of India. It belongs to the genus Saccharum (Saccharum spp. $2 n=70-140$ ) of the family Poaceae. Because of sweetness of stalk juice, it is domesticated from perennial grass species and cultivated for its stalks, which accumulate sucrose. The crop is grown in tropical and subtropical regions of the world. It contributes 60 per cent of the raw sugar produced world-wide, the remaining 40 per cent coming from sugar beet.

Sugarcane is considered as long durated crop and lazgman's crop its production is affected by different 'pests problems. It suffers from many diseases caused by fungi, bacteria, viruses, nematodes and also abiotic stresses. Among the fungal diseases, several pathogenic and saprophytic foliar fungal diseases viz., rust, smut, yellow spot, ring spot and brown spot have been reported in sugarcane plant in several parts of the world. Because of increased area of cultivation and continuous spread of same crop. Hither to causing losses both qualitatively and quantitatively. Minor diseases have reached the proportion of covering larger area. Thus ring spot and brown spot diseases which sporadically have become frequent occurring diseases in some parts of northern Karnataka. This has made to draw attention of sugarcane scientists to initiate some work. Survey of literature suggested that there is no much systematic work carried out on various aspects on brown spot diseases except reporting of the diseases and description of symptoms.

Butler and Singh as early as in 1934 reported brown spot (Cercospora longipes Butler) of sugarcane. Symptoms appear as large number of minute, reddish, rust like spots on both the surfaces of leaves. As infection progresses, spots coalesce and complete distortion of leaves takes place. From the literature it is seen that, Cercospora sp. usually does not grow readily on artificial media and so far only a few species have been successfully isolated (Jamadar, 1988) [7]. Thus, isolation on lab media and proving pathogenicity of Cercospora is very necessary to confirm the association of sugarcane with pathogen and it helps for further studies on 
epidemiology and management aspects. Management of plant diseases done by different chemical and non-chemical methods. Brown spot disease is as a miner and novel emerging disease in the recent years which sporadically has become frequent occurring disease in major sugarcane growing area of northern Karnataka. Hence, there is a scope for initiate the fascinating field of research on noval brown spot of sugarcane includes isolation of Cercospora pathogen, proving pathogenicity of Cercospora is very necessary to confirm the association of sugarcane with pathogen, identification by morphological and cultural studies necessary for advance research, need to studies on bio efficacy of different systemic, non-systemic, combi-product fungicides for chemical management of brown spot disease, need to focus on biocontrol agents and botanicals under laboratory condition is also necessary for non-chemical management of brown spot disease. Overall basic research helps to studies on epidemiological research and integrated diseases management practices for brown spot disease of sugarcane. Considering the aforementional facts, a research programme was formulated.

\section{Material and Methods \\ Isolation, identification and proving pathogenicity of pathogen}

Sugarcane leaves infected with brown spot were collected from different places (viz., Belagavi, Bagalkote, Dharwad and Uttar Kannada) during survey and used for isolation of the pathogen. Their isolation was done by following standard tissue isolation technique. The Cercospora longipes was identified based on its morphological and cultural characters like any other members of genus Cercospora. Later the pathogenicity for brown spot pathogen was proved through Koch's Postulation.

\section{In vitro evaluation of fungicides, bio agents and botanicals}

The bio efficacy of five systemic fungicides (at the concentration of $0.05 \%, 0.1 \%$ and $0.15 \%$ ) four non-systemic fungicides (at the concentration of $01 \%, 0.2 \%$ and $0.3 \%$ ) and five combi-products (at the concentration of $0.05 \%, 0.1 \%$ and $0.2 \%$ ) were assayed in vitro against Cercospora longipes for radial growth inhibition using poison food technique. A control plate having only the test pathogen was also kept for comparison. Three replications were maintained for each isolate. Per cent inhibition of mycelial growth over control was calculated by using the formula given by Vincent (1947) [16]. After recording all the observations they were tabulated and analysed statistically for further interpretation.

The antagonistic effects of five bioagents were evaluated against Cercospora longipes for radial growth inhibition using dual culture technique. A control plate having only the test pathogen was also kept for comparison. Three replications were maintained for each isolate. The per cent inhibition of the growth of the pathogen was calculated by the formula given by Vincent (1947) ${ }^{[16]}$. The antifungal mechanism of seven plant extract were evaluated against Cercospora longipes by using the poisoned food technique (Nene and Thapliyal, 1973) ${ }^{[10]}$. Controls were also maintained by growing the pathogens on PDA plates. Then such plates were incubated at $27 \pm 1^{0} \mathrm{C}$ and radial growth was taken when maximum growth was observed in control plate. The efficacy of plant product or botanicals was expressed as per cent inhibition of radial growth over the control which was calculated by using Vincent (1947) ${ }^{[16]}$ formula.

\section{Results}

The isolation of Cercospora longipes from the infected leaves was made as described in standard tissue isolation technique. The Cercospora longipes was identified based on its morphological and cultural characters like any other members of genus Cercospora. The colonies of $C$. longipes were uniformly dense on potato dextrose agar. The colonies appeared whitish colored, rough colony with circular to irregular sharp edges. The medium beneath the colony became dark brownish with yellow margin and cracking of colony at center appeared. Hyphae of the fungus were hyaline and septate. The fungus grew very slowly on PDA medium reaching a maximum growth of $60-75 \mathrm{~mm}$ and there was negligible sporulation in the medium. The culture was identified based on mycelial characters like knotted mycelium and spore morphology and the spore size. The conidia were hyaline, two to many celled, needle shaped, slightly broader at one end and pointed at the other end and conidiophores were in cluster. Based on these characters the pathogen was identified as $C$. longipes. The pathogenicity of the $C$. longipes was conformed once again through Koch's postulation and the symptoms of brown spot started developing on inoculated plants 7 to 8 days after mycelial bit inoculation. Sporulation of $C$. longipes also noticed in inoculated plant with mycelial bit after section of reisolated plant tissues and it produced cluster of conidiophores with shy conidia.

\section{In vitro evaluation of fungicides against $C$. longipes}

All the fungicides evaluated were significantly superior over the control with respect to per cent mycelial inhibition. Results have been presented in Table 1. Among the systemic fungicides, complete mycelial inhibition was recorded in hexaconazole, propiconazole and tebuconazole at all the concentration which found significantly superior over rest of the treatments. The least inhibition of mycelial growth was observed in thiophonate methyl $(28.72 \%)$ at 0.05 per cent. Irrespective of concentrations of fungicides tested, the hexaconazole, propiconazole and tebuconazole recorded maximum mean per cent mycelial inhibition (100\%) followed by carbendazim $(63.56 \%)$ and least per cent mycelial inhibition was recorded in thiophonate methyl (37.61\%).Among the non-systemic fungicides, complete mycelial inhibition was recorded in mancozeb (100\%) at 0.2 per cent and 0.3 per cent concentrations which found significantly superior over rest of the treatments and it was followed by mancozeb $(90.26 \%)$ at 0.3 per cent. The least inhibition of mycelial growth was observed in captan $(48.21 \%)$ at 0.1 per cent. Irrespective of concentrations of fungicides tested, the treatment involving mancozeb recorded maximum mean per cent mycelial inhibition $(96.75 \%)$ and least per cent mycelial inhibition was recorded in captan $(57.26 \%)$ at 0.1 per cent have been presented in Table 2 .

Among the four combi-fungicides, complete mycelial inhibition was recorded in treatment with cabendazim $12 \%+$ mancozeb $63 \%$, hexaconazole $18 \%$ + zineb $68 \%$ and captan $70 \%+$ hexaconazole $5 \%$ at all the concentration at all the three concentrations and Carboxin $37.55 \%+$ thiram $37.55 \%$ at 0.1 and 0.2 per cent concentration. which was found significantly superior over all other treatments and the least per cent inhibition of mycelial growth was observed which are trycyclozole $18 \%$ + mancozeb $62 \%$ WP $(68.03 \%)$

Irrespective of concentration of fungicides tested, the treatment involving cabendazim $12 \%+$ mancozeb $63 \%$, hexaconazole $18 \%$ + zineb $68 \%$ and captan $70 \%+$ 
hexaconazole $5 \%$ recorded maximum mean per cent mycelial inhibition $(100 \%)$ which was found to be on par with Carboxin $37.55 \%$ + Thiram 37.55\% (96.58\%) and least per cent mycelial inhibition was recorded in trycyclozole $18 \%+$ mancozeb $62 \%$ WP $(77.49 \%)$ at 0.1 per cent have been presented in Table 3.

Table 1: In vitro evaluation of systemic fungicides against C. longipes

\begin{tabular}{|c|c|c|c|c|}
\hline \multirow{3}{*}{ Systemic fungicide } & \multicolumn{3}{|c|}{ Per cent inhibition of radial growth over control } & \multirow{3}{*}{ Mean } \\
\hline & \multicolumn{3}{|c|}{ Concentration (\%) } & \\
\hline & $0.05 \%$ & $0.1 \%$ & $0.15 \%$ & \\
\hline Carbendazim & $59.66(50.55)^{*}$ & $64.96(53.68)$ & $66.15(54.40)$ & $63.59(52.88)$ \\
\hline Hexaconazole & $100.00(89.96)$ & $100(89.96)$ & $100.00(89.96)$ & $96.29(83.47)$ \\
\hline Thiophanate methyl & $28.72(32.39)$ & $37.95(38.01)$ & $46.15(42.78)$ & $37.61(37.73)$ \\
\hline Propiconazole & $100.0(89.96)$ & $100.00(89.96)$ & $100.00(89.96)$ & $100.00(89.96)$ \\
\hline Tebuconazole & $100.00(89.96)$ & $100.00(89.96)$ & $100.00(89.96)$ & $100.00(89.96)$ \\
\hline \multirow{2}{*}{ Mean } & $77.68(70.57)$ & $80.58(72.32)$ & $82.46(79.00)$ & \\
\hline & \multicolumn{2}{|c|}{ S.E $\mathrm{m} \pm$} & \multicolumn{2}{|c|}{ C.D at $1 \%$} \\
\hline Fungicides $(\mathrm{F})$ & \multicolumn{2}{|c|}{0.096} & \multicolumn{2}{|c|}{0.37} \\
\hline Concentrations (C) & \multicolumn{2}{|c|}{0.075} & \multicolumn{2}{|c|}{0.29} \\
\hline $\mathrm{F} \times \mathrm{C}$ & \multicolumn{2}{|c|}{0.167} & \multicolumn{2}{|c|}{0.65} \\
\hline
\end{tabular}

Figures in parentheses indicate Arcsine transformed values

Table 2: In vitro evaluation of non-systemic fungicides against $\mathrm{C}$. longipes

\begin{tabular}{|c|c|c|c|c|}
\hline \multirow{3}{*}{ Non systemic fungicide } & \multirow{2}{*}{\multicolumn{3}{|c|}{$\begin{array}{c}\text { Per cent inhibition of radial growth over control } \\
\text { Concentration }(\%)\end{array}$}} & \multirow{3}{*}{ Mean } \\
\hline & & & & \\
\hline & $0.1 \%$ & $0.2 \%$ & $0.3 \%$ & \\
\hline Copper oxy chloride & $84.96(67.15)^{*}$ & $86.15(68.13)$ & $88.37(70.04)$ & $86.50(68.44)$ \\
\hline Chlorothalonil & $56.41(48.66)$ & $59.83(50.65)$ & $88.37(54.71)$ & $60.97(51.34)$ \\
\hline Captan & $48.21(43.95)$ & $57.78(49.45)$ & $65.81(54.20)$ & $57.26(49.20)$ \\
\hline Mancozeb & $90.26(71.78)$ & $100.00(89.96$ & $100(89.96)$ & $96.75(83.90)$ \\
\hline \multirow{2}{*}{ Mean } & $69.96(57.89)$ & $75.94(64.55)$ & $80.21(67.23)$ & \\
\hline & \multicolumn{2}{|c|}{ S.Em \pm} & \multicolumn{2}{|c|}{ C.D at $1 \%$} \\
\hline Fungicides $(\mathrm{F})$ & \multicolumn{2}{|c|}{0.135} & \multicolumn{2}{|c|}{0.53} \\
\hline Concentrations (C) & \multicolumn{2}{|c|}{0.117} & \multicolumn{2}{|c|}{0.46} \\
\hline $\mathrm{F} \times \mathrm{C}$ & \multicolumn{2}{|c|}{0.234} & \multicolumn{2}{|c|}{0.92} \\
\hline
\end{tabular}

Figures in parentheses indicate Arcsine transformed values

Table 3: In vitro evaluation of combi products against $\mathrm{C}$. longipes.

\begin{tabular}{|c|c|c|c|c|}
\hline \multirow{3}{*}{ Combi products } & \multirow{2}{*}{\multicolumn{4}{|c|}{$\frac{\text { Per cent inhibition of radial growth over control }}{\text { Concentration }(\%)}$}} \\
\hline & & & & \\
\hline & $0.05 \%$ & $0.1 \%$ & $0.2 \%$ & Mean \\
\hline Trycyclozole18\% + Mancozeb 62\% WP (Merger) & $68.03(55.55)$ & $75.73(60.46)$ & $88.72(70.35)$ & $77.49(62.12)$ \\
\hline Carbendazim 12\% + Mancozeb 63\% WP (Saaf) & $100.00(89.96)$ & $100.00(89.96)$ & $100.0(89.96)$ & $100.0(84.98)$ \\
\hline $\begin{array}{c}\text { Carboxin } 37.5 \%+\text { Thiram } 37.5 \% \text { WP (Vitavax } \\
\text { power) }\end{array}$ & $89.74(71.29)$ & $100.00(89.96)$ & $100.0(69.08)$ & $96.58(83.74)$ \\
\hline Hexaconazole 4\% + Zineb 68\% WP (Avatar) & $100.00(89.96)$ & $100.00(89.96)$ & $100.0(89.96)$ & $100.0(84.98)$ \\
\hline Captan 70\% + Hexaconazole 5\% WP (Taqat) & $100.0(89.96)$ & $100.0(89.96)$ & $100.0(89.96)$ & $100.0(84.98)$ \\
\hline \multirow{2}{*}{ Mean } & $91.56(79.35)$ & $95.15(84.06)$ & $97.46(86.04)$ & \\
\hline & \multicolumn{2}{|c|}{ S.Em \pm} & \multicolumn{2}{|c|}{ C.D at $1 \%$} \\
\hline Fungicides $(\mathrm{F})$ & \multicolumn{2}{|c|}{0.078} & \multicolumn{2}{|c|}{0.30} \\
\hline Contrations $(\mathrm{C})$ & \multicolumn{2}{|c|}{0.061} & \multicolumn{2}{|c|}{0.24} \\
\hline $\mathrm{F} \times \mathrm{C}$ & \multicolumn{2}{|c|}{0.136} & \multicolumn{2}{|c|}{0.53} \\
\hline
\end{tabular}

Figures in parentheses indicate Arcsine transformed values

\section{In vitro evaluation of bio-agents against $C$. longipes}

There was a significant difference between the fungal and bacterial bio-agents on per cent inhibition of mycelial growth of $C$. longipes have been presented in Table 4. In this case also fungal antagonists gave higher inhibition as compared to bacterial antagonists. Maximum inhibition (77.82\%) was noticed in Trichoderma virens followed by T. harzianum
(76.92\%) and T. viride (76.15\%) which were on par with each other. The least inhibition of mycelial growth was observed in Verticilium lecanii (46.92\%) Between bacterial bio-agents tried Pseudomonas fluorescens gave maximum inhibition of mycelial growth $(56.15 \%)$. The least inhibition of mycelial growth was observed in Bacillis subtilis to the extent of 49.81 per cent 
Table 4: In vitro evaluation of bioagents against $\mathrm{C}$. longipes.

\begin{tabular}{|c|c|c|c|}
\hline \multirow{2}{*}{ Botanicals } & \multicolumn{3}{|c|}{ Per cent inhibition of mycelial growth } \\
\cline { 2 - 4 } & $\mathbf{5}$ & $\mathbf{1 0}$ & Concentration (\%) \\
\cline { 2 - 4 } & $38.97(38.61)$ & $51.62(45.91)$ & $45.30(42.26)$ \\
\hline Azadirachta indica & $13.84(21.74)$ & $23.76(29.16)$ & $18.80(25.45)$ \\
\hline Cassia fistula L. & $5.47(13.41)$ & $14.19(22.04)$ & $9.83(17.73)$ \\
\hline Chromolaena odorata & $14.19(22.11)$ & $25.81(30.52)$ & $20.00(26.32)$ \\
\hline Eucalyptus sp & $28.03(31.95)$ & $51.62(45.91)$ & $39.83(38.93)$ \\
\hline Jatropha curcas & $37.44(37.71)$ & $45.81(42.58)$ & $41.62(40.14)$ \\
\hline Parthenium hysterophorus & $14.53(22.37)$ & $22.56(28.34)$ & $18.55(25.35)$ \\
\hline Pongamia pinnata L & $24.44(29.14)$ & \multicolumn{2}{|c|}{$30.96(32.63)$} \\
\hline \multirow{2}{*}{ Mean } & S.E m \pm & \multicolumn{2}{|c|}{2.16} \\
\hline Botanicals (B) & 0.55 & \multicolumn{2}{c|}{1.16} \\
\hline Concentrations(C) & 0.29 & \multicolumn{2}{|c}{3.06} \\
\hline B X C & 0.78 & \multicolumn{2}{|c|}{} \\
\hline
\end{tabular}

Figures in parentheses indicate Arcsine transformed values

\section{In vitro evaluation of Botanicals against $\boldsymbol{C}$. longipes}

Results relating to the effects of plant extracts on per cent inhibition of $C$. longipes are presented in Table 5. There was very less inhibition of mycelial growth in all the botanicals tested. Among the Seven botanicals tested at two concentrations (5\% and $10 \%)$ the maximum per cent mycelial inhibition was recorded in treatment involving Azadirachta indica $(51.62 \%)$ and Jatropha curcas $(51.62 \%)$ at 10 per cent concentrations which was found to be significantly superior over rest of the treatments this was followed by Parthenium hysterophorus $(45.81 \%)$ at 10 per cent. The least inhibition of mycelial growth was observed in Chromolaena odorata at 5 per cent $(5.47 \%)$. Irrespective of concentrations of plant extracts tested, the treatment involving Azadirachta indica recorded maximum mean per cent mycelial inhibition (45.30\%) followed by Parthenium hysterophorus $(41.61 \%$ ) and minimum mean mycelial inhibition was recorded in Chromolaena odorata (37.61\%).

Table 5: In vitro evaluation of bioagents against Cercospora longipes

\begin{tabular}{|c|c|}
\hline Bio agents & $\begin{array}{c}\text { Per cent inhibition of mycelial } \\
\text { growth(mm) }\end{array}$ \\
\hline Bacillus subtiles & $49.81(34.82)$ \\
\hline Pseudomonas fluorescens & $56.15(32.25)$ \\
\hline Trichoderma harzianum & $76.92(22.78)$ \\
\hline Trichoderma viride & $76.15(23.17)$ \\
\hline Trichoderma virens & $77.82(22.30)$ \\
\hline Verticilium lecanii & $46.92(35.95)$ \\
\hline SEm \pm & 0.15 \\
\hline CD at $1 \%$ & 0.63 \\
\hline
\end{tabular}

\section{Discussion}

The brown spot (Cercospora longipes Butler) of sugarcane is foliar disease which was first reported by Butler and Singh (1934). Survey of literature suggested there is no much systematic work on various aspects on brown spot sugarcane disease except reporting and description of symptoms. The information available on brown spot disease and causal pathogens is very scanty. The identity of the $C$. longipes was done by studying its morphological and growth characteristics and were compared with earlier reports. Colonies appeared uniformly dense, initially white in colour later turned to light brown colour The identity of the fungus was confirmed by comparing the characters with earlier report given by Butler (1906) in case of sugarcane and Bhat et al. (2008) in case of pepper. Similarly pathogenicity study was taken up by artificial inoculation with mycelial bit methods and symptoms started developing on inoculated plants 7 to 8 days after inoculation. Such pathogenicity studies are also done by other workers and similar symptoms were described by Butler (1892) in case of sugarcane, Veena (2012) and Kavyashree (2014) ${ }^{[8]}$ in case of $C$. canenscens on greengram.

Among the systemic fungicides hexaconazole, propiconazole and tebuconazole at all the concentration showed 100 per cent inhibition of mycelial growth. Similar findings were reported by Satyaprashant (2004), Swamy (2010) ${ }^{[14]}$ and Veena (2013) [15] who reported that, Hexaconazole @ 0.05\% and combiproduct, carbendazim + mancozeb @ $0.025 \%$ recorded complete inhibition of mycelial growth of $C$. canescens. In case of non-systemic fungicides, The 100 per cent mycelial inhibition was recorded in mancozeb at 0.2 and 0.3 per cent concentrations. These findings are in conformity with work of Hemachandra (2013) ${ }^{[6]}$ who reported that copper oxichloride, mancozeb, thiram $(0.25 \%)$ and chlorothalonil $(0.2 \%)$ were effective with 100 per cent inhibition against $C$. beticola. In case of four combi products, cabendazim $12 \%+$ mancozeb $63 \%$, hexaconazole $18 \%+$ zineb $68 \%$ and captan $70 \%+$ hexaconazole $5 \%$ at all the concentrations and carboxin $37.55 \%$ + thiram $37.55 \%$ at 0.1 and 0.2 per cent concentration showed 100 per cent inhibition of mycelia growth. These findings are in conformity with work of Swamy (2010) ${ }^{[14]}$ in case of Cercospora capsici in chilli.

Among fungal bioagents tried, Trichoderma virens (77.82\%) T. harzianum (76.92\%) and T. viride $(76.15 \%)$ were found to inhibit mycelial growth of $C$. longipes in that order. However, $P$. fluorescens $(56.15 \%)$ as a bacterial antagonist was found less effective. Higher efficacy by fungal antagonists may be due to antibiosis mechanism as reported by Brain (1951) ${ }^{[4]}$ in Trichoderma spp. or mycoparasitism mechanism as reported by Mukherjee et al. (2000). Similar results are reported by Siddaramaiah (1986) ${ }^{[13]}$ in case of leaf spot of mulberry caused by $C$. moricola. Prashanth (2004) ${ }^{[11]}$ in case of $C$. kikuchii and Veena (2012) in case of leaf spot of greengram for the higher efficacy of fungal antagonists. A. indica $(51.62 \%)$ and Jatropha curcas $(51.62 \%)$ at 10 per cent concentration showed highest inhibition and indicating plant extracts may be better for $C$. longipes. These findings are in conformity with work of Asaduzzaman (2013) ${ }^{[3]}$ reported that, garlic tablet solution of $1: 1 \mathrm{w} / \mathrm{v}$ concentration against $C$. capsici was found promising in inhibiting radial mycelia growth in laboratory conditions. Hemachandra (2013) ${ }^{[6]}$ and Smamy (2010) also found mycelial inhibition of Cercospora spp. in sugarbeet and chilli crops by plant extracts 


\section{References}

1. Anonymous, 2018a. http://www.indiastat.com

2. Anonymous. Final estimation of area, production and yield of principle crops in Karnataka for the year 2014. Directorate of Economics and Statistics, Bangalore, 2018b, 118.

3. Asaduzzaman M, Hossain MM, Parvez MN, Islam MA, Meah MB. Effect of dose and frequency of garlic tablet spray on the incidence of cercospora leaf spot of chilli. J Agrofor. Environ. 2013; 7(1):119-122.

4. Brain PW. Antibiotics produced by fungi, Botanical Rev. 1951; 17:357-370.

5. Butler EJ, Singh S. Fungal disease of sugarcane in Bengal. Mem. Dept. Agric. India. 1934; 1(3):1-53.

6. Hemachandra H, Jadesha G, Prakasam V. Efficacy of fungicides and botanicals against Cercospora beticola Sacc. in sugarbeet. Bioinfolet. 2013; 10(2):473-479.

7. Jamadar MM. Studies on leaf spot of greengram (Vigna radiata L.) Wilczek caused by Cercospora canescens Ell. and Mart., M. Sc. (Agri.) Thesis, Univ. Agri. Sci., Dharwad, Karnataka (India), 1988.

8. Kavyashree MC. Studies on fungal foliar diseases of greengram Vigna rodiata (L.) Wilczek. M. Sc. (Agri.) Thesis, Univ. Agric. Sci. Dharwad, Karnataka (India), 2014.

9. Mukherjee N. Antifungal activities of some oils and detergents II. Effect of germtubes growth, sclerotia plant pathogen. Zpflkranth Pflactutz. 1976; 83:305-308.

10. Nene YL, Thapliyal PN. Fungicide in Plant Diseases Control, (Third Edition; Oxford and IBH publishing Co. Pvt. Ltd., New Delhi, 1973, 325.

11. Prashanth SP. Investigation on purple seed stain of soybean caused by Cercospora kikuchii. M. Sc. Thesis, Univ. Agric. Sci., Dharwad, Karnataka (India), 2004.

12. Satyaprasanth P. Investigations on purple seed stain of soybean caused by Cercospora kikuchii. M. Sc. Thesis, Univ. Agric. Sci., Dharwad, Karnataka (India), 2004.

13. Siddaramaiah AL. Studies on leaf spot of mulberry (Morus alba L.) caused by Cercospora moricola with special reference to epidemiology and control. Ph. D. Thesis, Univ. Agric. Sci., Bangalore, Karnataka (India), 1986.

14. Swamy KM. Epidemiology and management of leaf spot of chilli (Capsicum annuum L.) caused by Cercospora capsici heald and wolf. M. Sc. (Agri.) Thesis, Univ. Agric. Sci., Raichur, Karnataka (India), 2010.

15. Veena Yashoda RH, Ganajaxi M, Vijaykumar AG, 2013. Bioefficacy of fungicides against Cercospora canescens causing leaf spot of greengram, Crop Res. 2010; 46(1, 2\&3):74-78.

16. Vincent JM. Distortion of fungal hyphae in the presence of certain inhibitors. Nature. 1947; 150:850. 